\title{
Comprehensive Genomic Profiling Reveals Diverse but Actionable Molecular Portfolios across Hematologic Malignancies: Implications for Next Generation Clinical Trials
}

\author{
Natalie Galanina ${ }^{1, *(1)}$, Rafael Bejar ${ }^{1}$, Michael Choi ${ }^{1}$, Aaron Goodman ${ }^{1,2}$, \\ Matthew Wieduwilt ${ }^{1,2}$, Carolyn Mulroney ${ }^{1,2}$, Lisa Kim ${ }^{1}$, Huwate Yeerna ${ }^{3}$, Pablo Tamayo ${ }^{3}$ (D), \\ Jo-Anne Vergilio $^{4}$, Tariq I. Mughal ${ }^{4,5}$, Vincent Miller ${ }^{4}$, Catriona Jamieson ${ }^{1}$ and \\ Razelle Kurzrock ${ }^{1}$ \\ 1 Department of Medicine, Division of Hematology/Oncology and Center for Personalized Cancer Therapy, \\ University of California San Diego, 3855 Health Science Drive \#0987, La Jolla, CA 92093, USA; \\ rabejar@ucsd.edu (R.B.); mychoi@ucsd.edu (M.C.); a1goodman@ucsd.edu (A.G.); \\ mwieduwilt@ucsd.edu (M.W.); camulroney@ucsd.edu (C.M.); lit003@ucsd.edu (L.K.); \\ cjamieson@ucsd.edu (C.J.); rkurzrock@ucsd.edu (R.K.) \\ 2 Department of Medicine, Division of Blood and Marrow Transplantation, University of California San Diego, \\ La Jolla, CA 92093, USA \\ 3 Department of Medicine, Division of Statistical Physics, University of California San Diego, \\ La Jolla, CA 92093, USA; hyeerna@ucsd.edu (H.Y.); ptamayo@ucsd.edu (P.T.) \\ 4 Foundation Medicine Inc., Cambridge, MA 02141, USA; jvergilio@foundationmedicine.com (J.-A.V.); \\ tmughal@foundationmedicine.com (T.I.M.); vmiller@foundationmedicine.com (V.M.) \\ 5 Tufts University Medical Center, Boston, MA 02111, USA \\ * Correspondence: ngalanina@ucsd.edu; Tel.: +858-534-0195; Fax: +858-246-0075
}

Received: 19 November 2018; Accepted: 11 December 2018; Published: 21 December 2018

check for updates

\begin{abstract}
Background: The translation of genomic discoveries to the clinic is the cornerstone of precision medicine. However, incorporating next generation sequencing (NGS) of hematologic malignancies into clinical management remains limited. Methods: We describe 235 patients who underwent integrated NGS profiling (406 genes) and analyze the alterations and their potential actionability. Results: Overall, 227 patients $(96.5 \%)$ had adequate tissue. Most common diagnoses included myelodysplastic syndrome (22.9\%), chronic lymphocytic leukemia (17.2\%), non-Hodgkin lymphoma (13.2\%), acute myeloid leukemia $(11 \%)$, myeloproliferative neoplasm $(9.2 \%)$, acute lymphoblastic leukemia (8.8\%), and multiple myeloma (7.5\%). Most patients $(N=197 / 227$ $(87 \%))$ harbored $\geq 1$ genomic alteration(s); $170 / 227$ (75\%), $\geq 1$ potentially actionable alteration(s) targetable by an FDA-approved (mostly off-label) or an investigational agent. Altogether, 546 distinct alterations were seen, most commonly involving TP53 (10.8\%), TET2 (4.6\%), and DNMT3A $(4.2 \%)$. The median tumor mutational burden (TMB) was low (1.7 alterations/megabase); $12 \%$ of patients had intermediate or high TMB (higher TMB correlates with favorable response to anti-PD1/PDL1 inhibition in solid tumors). In conclusion, $96.5 \%$ of patients with hematologic malignancies have adequate tissue for comprehensive genomic profiling. Most patients had unique molecular signatures, and $75 \%$ had alterations that may be pharmacologically tractable with gene- or immune-targeted agents.
\end{abstract}

Keywords: next generation sequencing; lymphoid malignancies; myeloid malignancies; precision medicine 


\section{Introduction}

Recent advances in next generation sequencing (NGS) have allowed for unprecedented insights into the genomic alterations that underlie oncogenesis, tumor biology, and survival. NGS permits identification of genomic alterations that not only inform a more granular subclassification of disease with various prognostic and predictive features but may also guide therapy selection [1]. Cumulative gains in understanding of cancer genomics and immuno-oncology are being rapidly translated into clinical practice, particularly for metastatic solid tumors, shifting the treatment paradigm from cytotoxic chemotherapy to a biologically informed approach where oncogenic alterations are matched with targeted agents $[2,3]$. The drug-target pairing that aligns a deranged molecular pathway with a cognate therapeutic agent constitutes the hallmark of precision medicine, and has demonstrated superior response rates as compared to nonselective chemotherapy in tumors such as melanoma, lung cancer, and chronic myelogenous leukemia [4,5]. There is now a plethora of genotype-matched therapeutics that have been Food and Drug Administration (FDA)-approved for the treatment of advanced solid tumors across a wide array of histologies.

Matched targeted therapy has also proven effective in several hematologic malignancies. For instance, chronic myelogenous leukemia (CML) is the poster child for a disease transformed by matched targeted therapy. Indeed, imatinib mesylate, which inhibits the enzymatic activity of the aberrant $B C R-A B L 1$ kinase, the hallmark of CML, has extended overall survival to near-normal life expectancy. Despite the unequivocal success of tyrosine kinase inhibitors (TKI) in CML, these types of practice-changing, rationally developed, targeted agents have not been broadly implemented in the treatment of many lymphoid and myeloid malignancies. As a result, despite the vast heterogeneity of hematopoietic tumors, most of the patients suffering from these disorders are still treated with non-specific cytotoxic chemotherapy. While this "one size fits all" approach is effective for many patients, it is clear that a significant proportion of patients, particularly those with adverse prognostic features, often relapse. The poorer outcomes are arguably because, despite cytotoxic chemotherapy, the driver oncogenic alterations persist, uninhibited, in the residual post-chemotherapy clones. In the relapsed setting, the standard salvage regimens rely on more intensive chemotherapy, followed by hematopoietic stem cell transplantation (HSCT), often associated with poor tolerability and significant morbidity, particularly in older patients [6]. Thus, understanding the molecular crosstalk that leads to disease progression and selectively targeting alterations within these signaling pathways remains a critical and unmet medical need.

To date, intense investigation into molecular underpinnings of hematologic disease has led to the identification of key recurrent mutations such as $M Y D 88^{\mathrm{L} 265 \mathrm{P}}$ in lymphoplasmacytic lymphoma (LPL), BRAF ${ }^{\mathrm{V} 600 \mathrm{E}}$ in hairy cell leukemia (HCL), and FLT3 in acute myelogenous leukemia (AML) that can be successfully targeted with cognate agents-ibrutinib, vemurafenib, and midostaurin respectively; producing encouraging results [7-9]. Undoubtedly, further insight into the genomic landscape of hematologic malignancies may help elucidate key molecular alterations and potentially inform treatment selection.

Herein, we analyze the genomic profiles of 235 patients with various hematologic malignancies for whom comprehensive genomic profiling (CGP) had been performed. We examined the mutational burden as well as the type and frequency of potentially actionable alterations across a wide variety of hematologic diagnoses to better delineate the mutational landscape of these disorders, providing a foundation for precision medicine trials in the hematologic malignancy clinical setting.

\section{Results}

\subsection{Patient Characteristics}

Tumor samples from 235 patients (133 men (59\%) and 94 women (41\%)) were collected. Of these, 227 subjects $(96.5 \%)$ had adequate tissue quantity and purity for genomic analysis. Thirty patients had 
no genomic alterations, while $87 \%$ of patients $(197 / 227)$ demonstrated at least one molecular alteration (variants of unknown significance (VUSs) were excluded) (Figure 1).

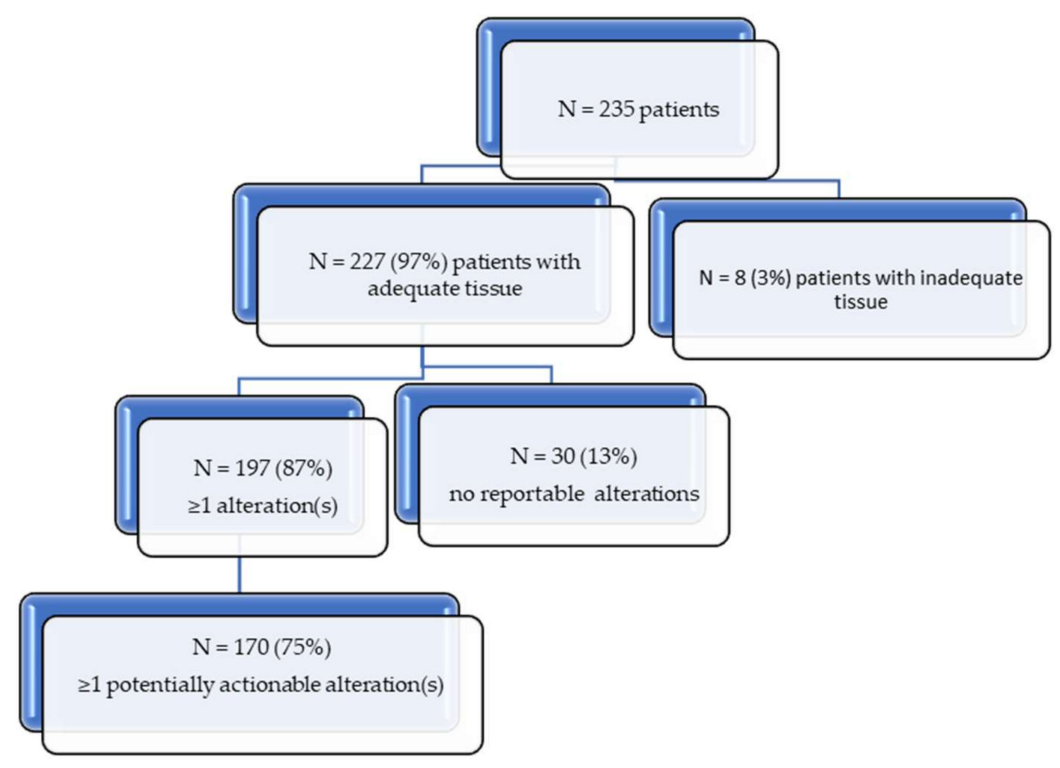

Figure 1. Consolidated Standards of Reporting Trials (CONSORT) diagram.

The most common malignancy in this cohort was myelodysplastic syndrome (22.9\%), chronic lymphocytic leukemia (17.2\%), non-Hodgkin lymphoma (13.2\%), acute myeloid leukemia (11\%), myeloproliferative neoplasm $(9.2 \%)$, acute lymphoblastic leukemia $(8.8 \%)$, and multiple myeloma (7.5\%) (Table 1). The most common tissue source for NGS analysis was peripheral blood $(\mathrm{N}=99$ patients $(44 \%))$ or bone marrow $(N=86(38 \%))$, followed by lymph node $(N=17(7 \%))$ and other $(N=25(11 \%))$.

Table 1. Patient characteristics ( $N=227$ patients with adequate tissue for comprehensive genomic profiling (CGP)).

\begin{tabular}{ll}
\hline \multicolumn{1}{c}{ Patient Demographics and Baseline Characteristics } \\
\hline $\begin{array}{l}\text { Gender: } \\
\text { Men (\%); Women (\%) }\end{array}$ & $133(59 \%) ; 94(41 \%)$ \\
\hline $\begin{array}{l}\text { Age: } \\
\text { Median age (range) }\end{array}$ & 59 years (17-88) \\
\hline $\begin{array}{l}\text { Ethnicity: } \\
\text { Caucasian (\%) }\end{array}$ & $163(71.8 \%)$ \\
\hline Asian (\%) & $18(8 \%)$ \\
\hline Hispanic (\%) & $18(8 \%)$ \\
\hline African American (\%) & $8(3.5 \%)$ \\
\hline Other (\%) & $20(8.8 \%)$ \\
\hline Histologies: & $N=\mathbf{1 2 4}(\mathbf{5 4 . 6} \%)$ \\
\hline Myeloid Disorders & $52(22.9 \%)$ \\
\hline Myelodysplastic syndrome (MDS) & $25(11 \%)$ \\
\hline Acute myeloid leukemia (AML) & $21(9.2 \%)$ \\
\hline Myeloproliferative neoplasia (MPN) & $17(7.5 \%)$ \\
\hline Multiple Myeloma (MM) & $4(1.8 \%)$ \\
\hline Chronic myeloid leukemia (CML) & $5(2.2 \%)$ \\
\hline Other myeloid disorders & $N=\mathbf{1 0 3}(\mathbf{4 5 . 4} \%)$ \\
\hline Lymphoid disorders & $39(17.2 \%)$ \\
\hline Chronic lymphocytic leukemia (CLL) & $20(8.8 \%)$ \\
\hline Acute lymphocytic leukemia (ALL) & \\
\hline
\end{tabular}


Table 1. Cont.

\begin{tabular}{ll}
\hline \multicolumn{2}{c}{ Patient Demographics and Baseline Characteristics } \\
\hline Diffuse large B-cell lymphoma (DLBCL) & $18(7.9 \%)$ \\
\hline Follicular lymphoma (FL) & $6(2.6 \%)$ \\
\hline Marginal zone lymphoma (MZL) & $4(1.8 \%)$ \\
\hline Anaplastic large cell lymphoma (ALCL) & $2(0.9 \%)$ \\
\hline Castleman disease & $2(0.9 \%)$ \\
\hline Other lymphoid disorders & $12(5.3 \%)$ \\
\hline Summary of alterations & $197(87 \%)$ \\
\hline Number of patients with alterations & $170(75 \%)$ \\
\hline Number of patients with potentially actionable alterations & $3(0-14)$ \\
\hline Median number of alterations/patient (range) & $1(0-7)$ \\
\hline Median number of potentially actionable alterations/patient (range) & 698 \\
\hline Total alterations & 546 \\
\hline Number of distinct alterations & 256 \\
\hline
\end{tabular}

\subsection{CGP Results}

The genomic landscape of distinct alterations identified across hematopoietic malignancies is depicted in Figure 2.

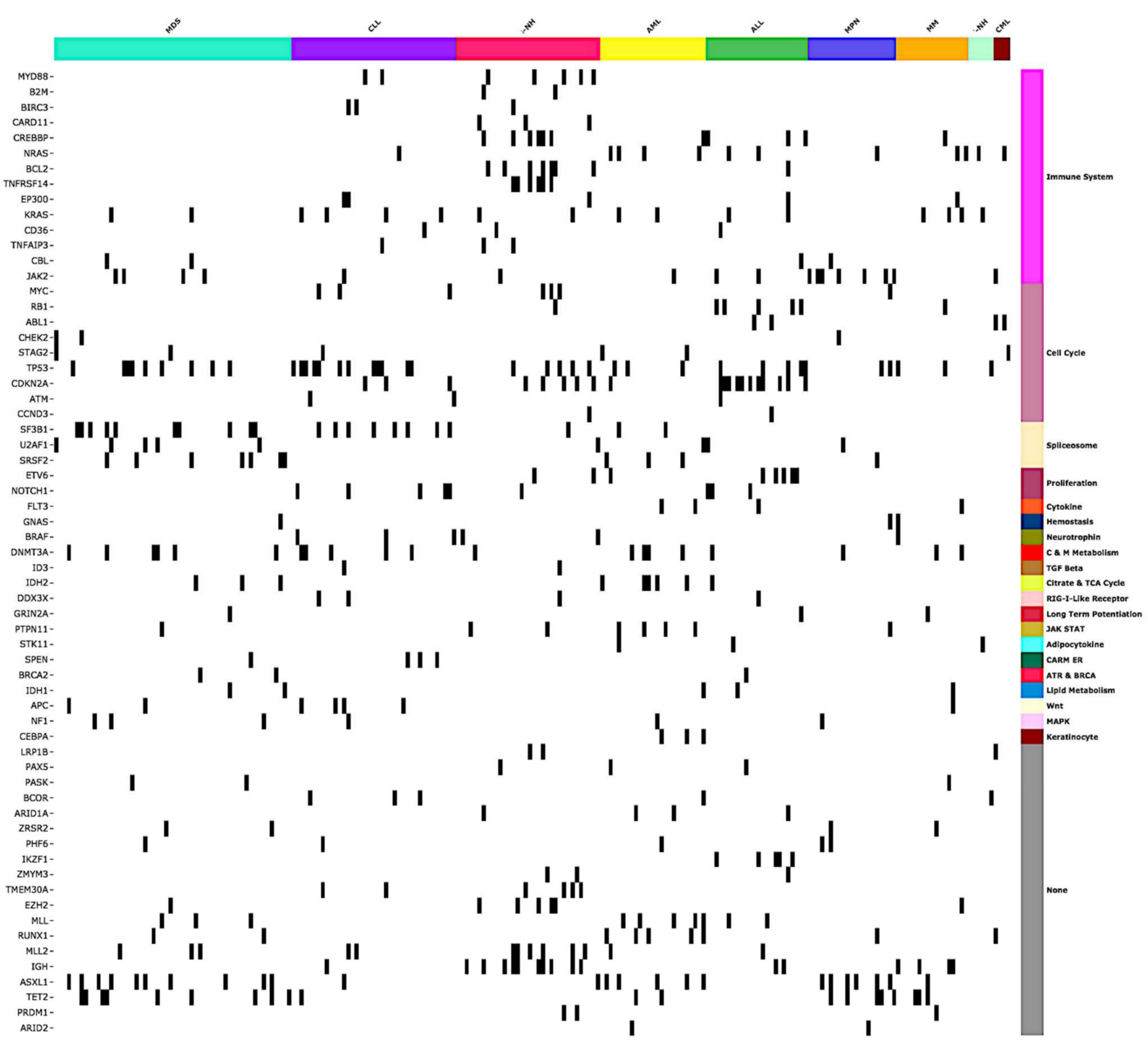

Figure 2. The genomic landscape of distinct, clinically relevant gene alterations across hematologic cancers. Molecular alterations are organized by gene sets derived from MSigDB Collection2 (Version 6.1) [10-12]. 
The median number of alterations detected per patient was 3 (range, $0-14$ ). The majority of patients $(N=197 / 227(87 \%))$ harbored at least one alteration. Of the total distinct aberrations, alterations in TP53 $(N=59)$, TET2 $(N=25)$ and DNMT3A $(N=23)$ were among the most frequent aberrations. (Figures 3 and 4 ).

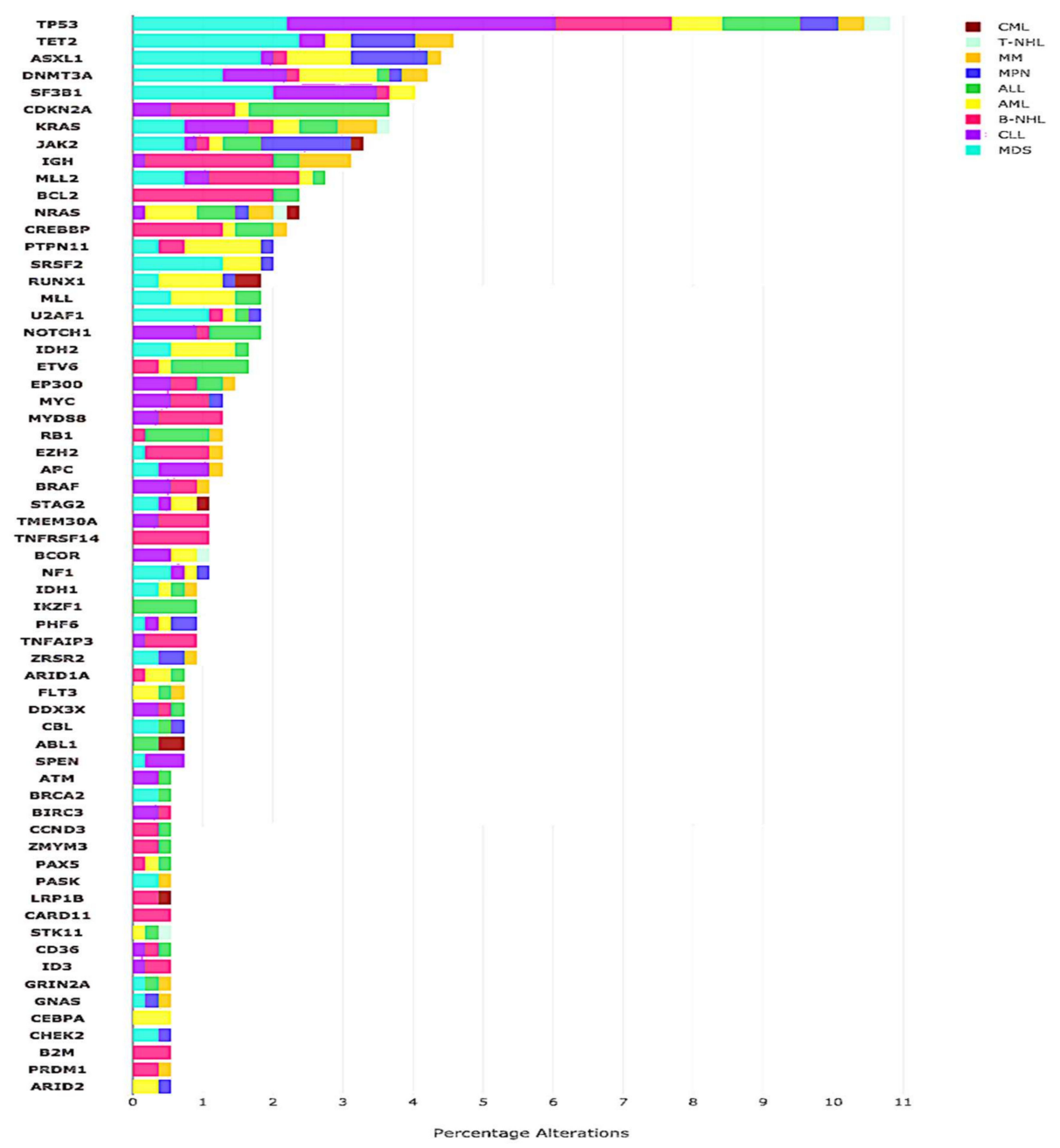

Figure 3. Frequency of most common alterations across various hematologic histologies.

A total of 546 distinct alterations were identified by NGS in the entire cohort of 227 patients (Table 1). Types of alterations identified included substitutions, indels, copy number alterations (CNAs), and gene fusions. The most frequent types of alterations were mutations ( $85 \%$ of all alterations (594/698)), followed by fusion/rearrangement (7\% (48/698)), copy loss $(6 \%(42 / 698))$, and copy gain/duplication/amplifications (2\% (14/698)) (Figure 5).

In at least one patient, one hundred and forty-eight distinct genes were altered. The vast majority of patients $(95.5 \%$ ) had distinct molecular profiles, $4.5 \%$ of patients had identical molecular signatures (solitary alterations that were identical in at least one other patient involving the following genes: JAK2 V617F (.5\%), TP53 R273H (1\%), SF3B1 K700E (1\%)). (An identical molecular portfolio/signature implies that both the genes involved and the precise loci altered in those genes were identical). 


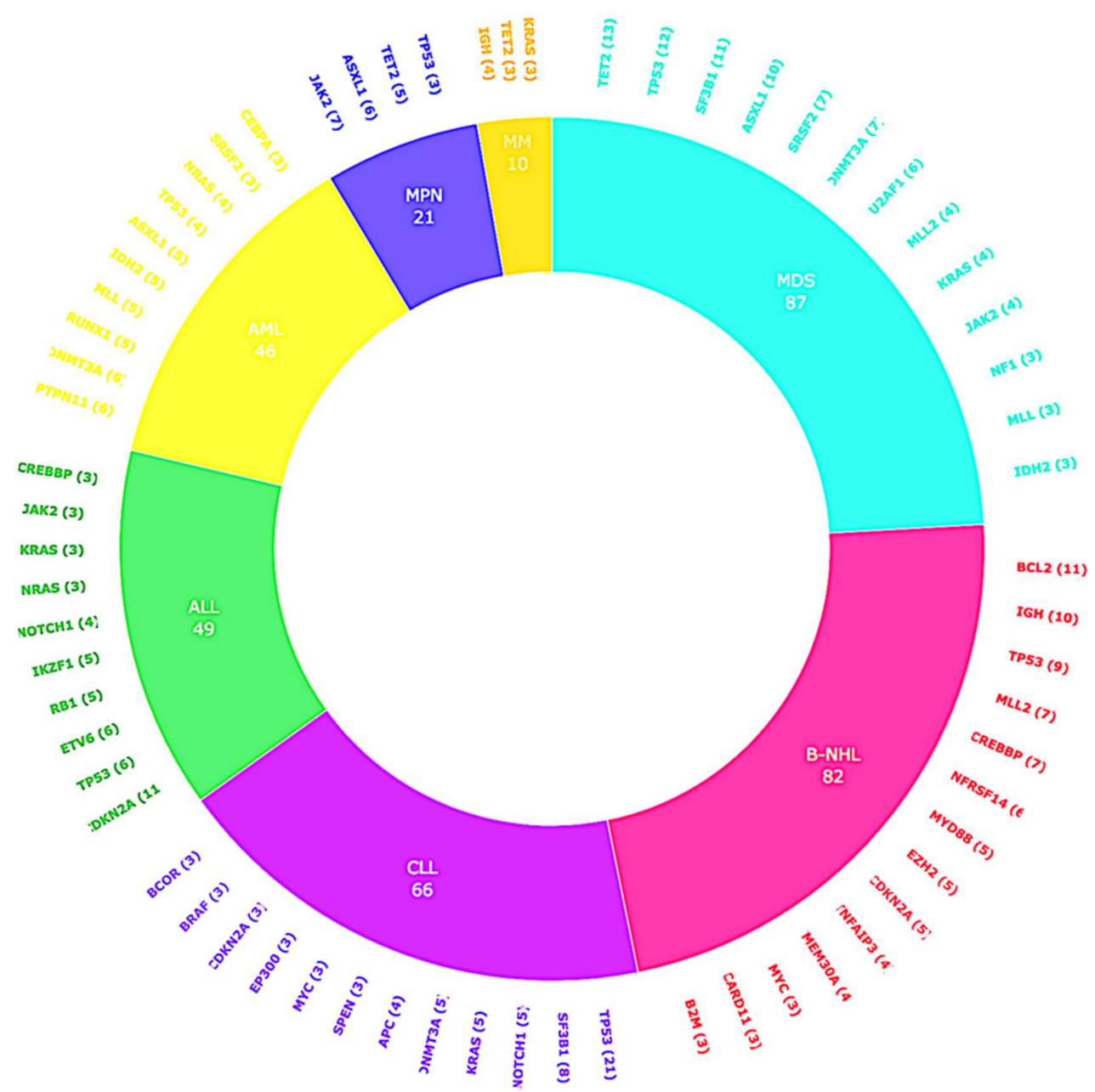

Figure 4. Overview of hematopoietic malignancies and most frequent alterations. The frequency of most common alterations per histology type. Total number of distinct alterations $N=546$. The graph displays unique alterations that occur in $\geq 3 \%$ of patients with the specified histology.

\section{Types of molecular alterations identified}

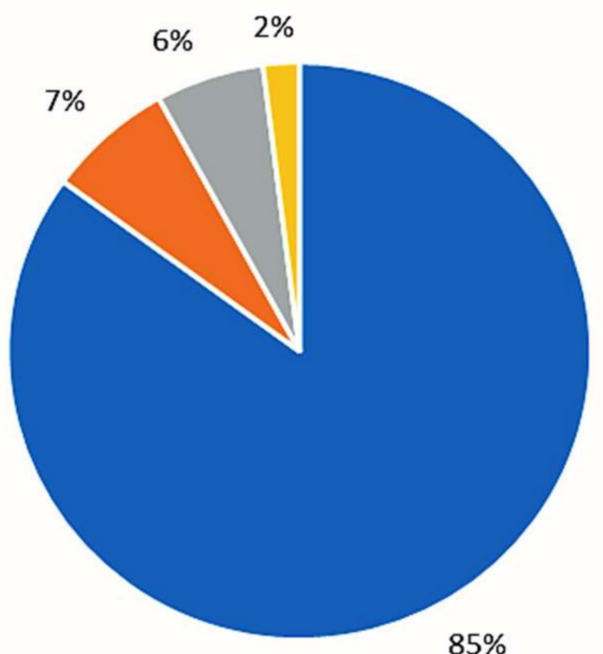

- Mutations/Insertions/Deletions

घ Fusion/Rearrangment

- Loss

- Amplification/Duplication

Figure 5. Types of molecular alterations identified. 


\section{3. $T M B$}

In our cohort, 219 patients had data for TMB. TMB ranged from 0.4 to 140, with a median TMB of 1.7 mutations per megabase. The majority of patients $(84 \%)$ had low TMB $(\leq 1-5$ mutations $/ \mathrm{MB})$; $12 \%$, intermediate TMB ( $>5$ to $\leq 19$ mutations $/ \mathrm{MB}$ ); and only $2 \%$, high TMB ( $\geq 20$ mutations $/ \mathrm{MB}$ ) (Figure 6). TMB of myeloid neoplasms was lower than that for lymphoid malignancies (median $=0.9$ mutations /MB (range, $0.8-12$ ) versus 2.5 (range, $0.4-140)(p=0.0012)$.

Tumor Molecular Burden (TMB) across hematologic malignancies $(\mathrm{N}=219)$

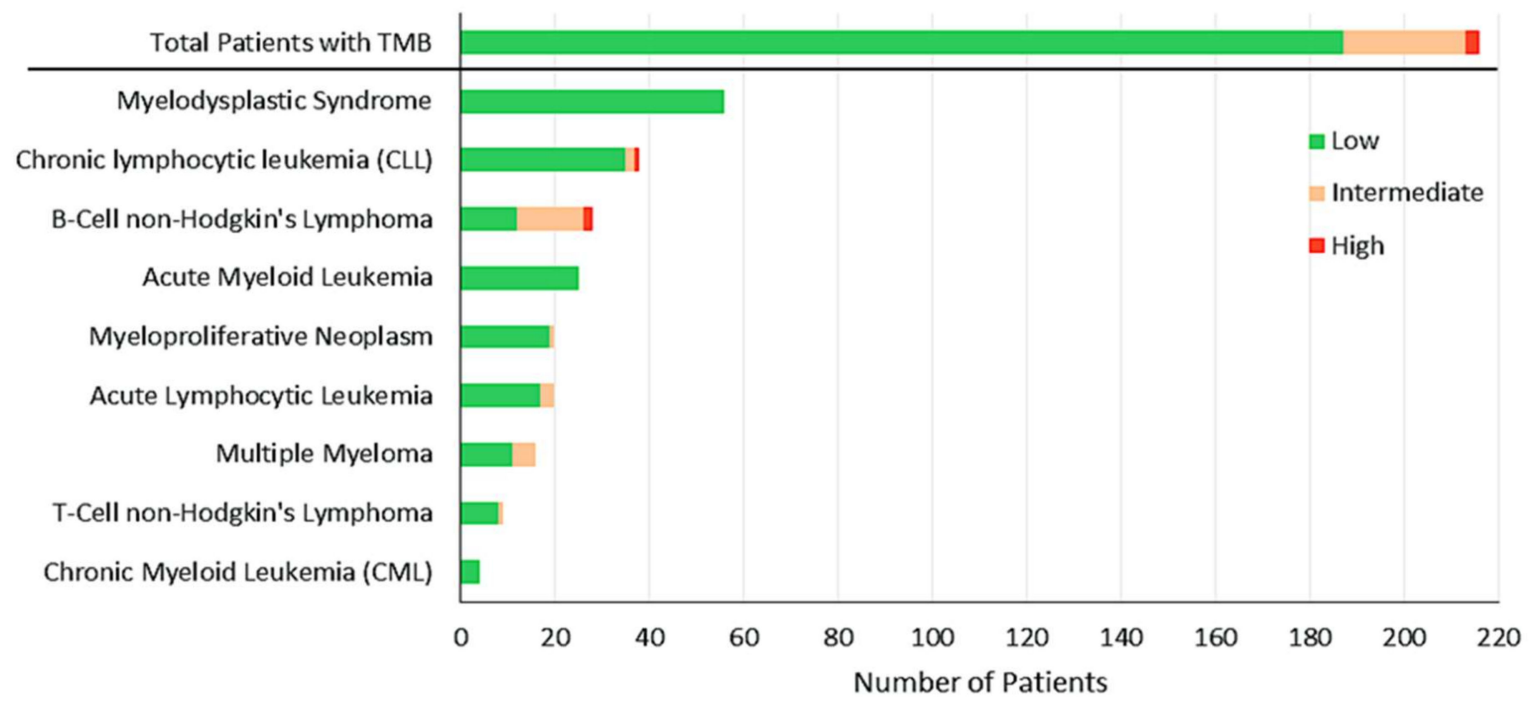

Figure 6. Tumor Mutation Burden (TMB) across hematologic malignancies. Note: $N=219$ total number of patients analyzed for TMB. The majority of patients $(84 \%)$ had low TMB $(\leq 1-5$ alterations $/ \mathrm{MB})$, $12 \%$ were found to have intermediate $\mathrm{TMB}$ ( $>5$ to $\leq 19$ alterations $/ \mathrm{MB}$ ), and only $2 \%$ of the patients harbored high TMB ( $\geq 20$ alterations $/ \mathrm{MB})$.

\subsection{Actionable Alterations}

Potentially actionable mutations were identified in $75 \%$ of patients with adequate tissue (170/227). Of these, 32 patients ( $14 \%$ of the 227 ) had $\geq 1$ alteration theoretically actionable by an on-label FDA approved drug; 112 patients ( $49 \%$ of 227), by an off-label FDA-approved drug; and, of the remainder, 26 patients had an alteration actionable by an experimental drug. Pharmacologically tractable aberrations were found across all hematological malignancies (Table 2). 
Table 2. Genomic alterations and examples of potential targeted (either on- or off- label) therapeutic.

\begin{tabular}{|c|c|c|c|c|}
\hline Gene Alteration & Gene Function & Examples of Potential on/off-Label Therapy & $\begin{array}{l}\text { Examples of Potential } \\
\text { Experimental } \\
\text { Therapy/Clinical Trial * }\end{array}$ & Ref. \\
\hline$A B L 1 / 2$ & $\begin{array}{l}\text { ABL (Abelson tyrosine-protein) kinase regulates cell survival and } \\
\text { division/differentiation }\end{array}$ & Imatinib, Dasatinib, Nilotinib, Bosutinib, Ponatinib & & \\
\hline$A P C$ & $\begin{array}{l}\text { APC (adenomatous polyposis coli) is a tumor suppressor, regulating cell } \\
\text { division/adhesion, controls Wnt signaling pathway }\end{array}$ & Sulindac (Tankyrase inh) & & [13] \\
\hline ARID1A & $\begin{array}{l}\text { ARID1A (AT-rich interactive domain-containing protein 1A) regulates } \\
\text { transcription }\end{array}$ & Dasatinib, EZH2 inh. & $\begin{array}{l}\text { Talazoparib Tosylate } \\
\text { NCT02286687** }\end{array}$ & \\
\hline ASXL1 & $\begin{array}{l}\text { ASXL1 (additional sex combs-like1) regulates transcription and } \\
\text { ubiquitin-proteasome protein degradation via BAP pathway. }\end{array}$ & Cabozantinib & & [14] \\
\hline ATM & $\begin{array}{l}\text { ATM (ataxia telangiectasia mutated) regulates DNA damage response } \\
\text { via the PI3K-like protein kinase pathway }\end{array}$ & Olaparib & & [15] \\
\hline$B C L 2$ & BCL2 (B-cell lymphoma 2) regulates apoptosis & Venetoclax & & [16] \\
\hline$B R A F$ & $\begin{array}{l}\text { BRAF regulates cell growth via MAPK (RAF-MEK-ERK) signaling } \\
\text { cascade }\end{array}$ & $\begin{array}{l}\text { Dabrafenib, Regorafenib, Trametinib, Vemurafenib, } \\
\text { Cobimetinib }\end{array}$ & & [17] \\
\hline$B R C A 2$ & BRCA2 (breast cancer 1/2) regulates DNA double-strand break repair & Olaparib, Niraparib, Rucaparib & & \\
\hline BRIP1 & BRIP1 (BRCA1-interacting protein 1) functions in DNA repair & Olaparib & & \\
\hline BTK & $\begin{array}{l}\text { BTK (Bruton's tyrosine kinase) regulates B-cell receptor signaling and } \\
\text { B-cell development }\end{array}$ & Ibrutinib, Acalabrutinib & & [18] \\
\hline CCND2 & CCND1/3 (cyclin D1/3) regulates cell cycle via CDK4/6 & Palbociclib & & [19] \\
\hline$C D 274$ & $\begin{array}{l}\text { CD274 (cluster of differentiation 274) encodes immune inhibitory } \\
\text { receptor B7-H1, also known as programmed cell death ligand-1 (PD-L1) }\end{array}$ & $\begin{array}{l}\text { Atezolizumab, Avelumab, Durvalumab, } \\
\text { Nivolumab, Pembrolizumab }\end{array}$ & & \\
\hline$C D 79 B$ & $\begin{array}{l}\text { CD79A/B (cluster of differentiation 79) complexes with B-cell receptor, } \\
\text { mediates downstream signaling to the NF-kB, PI3K, MAPK and NF-AT } \\
\text { pathways }\end{array}$ & Ibrutinib & Polatuzumab vedotin & [20] \\
\hline CDK4 & CDK4 (cyclin-dependent kinase 4) regulates cell cycle & Palbociclib, Ribociclib & & [19] \\
\hline$C D K N 2 A / B$ & $\begin{array}{l}\text { CDKN2A (cyclin dependent kinase inhibitor encodes tumor suppressors } \\
\text { and regulates cell cycle; loss results in increased CDK4/6 }\end{array}$ & Palbociclib, Ribociclib & & [19] \\
\hline CSF1R & CSF1 (colony stimulating factor 1) regulates differentiation and survival & & Chiauranib NCT03074825** & \\
\hline CXCR4 & $\begin{array}{l}\text { CXCR4 (C-X-C chemokine receptor type } 4) \text { regulates hematopoiesis and } \\
\text { CD20 expression }\end{array}$ & Plerixafor & BMS-936564 NCT01120457 ** & [21] \\
\hline DNMT3A & DNMT3A (DNA methyltransferase 3A) regulates gene expression & Azacitidine, Decitabine & & [22] \\
\hline EP300 & $\begin{array}{l}\text { Histone acetyltransferase p300 regulates transcription via chromatin } \\
\text { remodeling }\end{array}$ & & Mocetinostat NCT02282358** & \\
\hline ERBB4 & $\begin{array}{l}\text { Member of the EGFR (epidermal growth factor receptor) regulates } \\
\text { proliferation }\end{array}$ & $\begin{array}{l}\text { Trastuzumab, Pertuzumab Afatinib, Erlotinib, } \\
\text { Lapatinib }\end{array}$ & & \\
\hline
\end{tabular}


Table 2. Cont.

\begin{tabular}{|c|c|c|c|c|}
\hline Gene Alteration & Gene Function & Examples of Potential on/off-Label Therapy & $\begin{array}{l}\text { Examples of Potential } \\
\text { Experimental } \\
\text { Therapy/Clinical Trial * }\end{array}$ & Ref. \\
\hline EZH2 & $\begin{array}{l}\text { EZH2 (enhancer of zeste-homolog 2) regulates DNA methylation and } \\
\text { transcription repression }\end{array}$ & & Tazemetostat (NCT02601950) ** & [23] \\
\hline FGFR3 & $\begin{array}{l}\text { FGFR3 (fibroblast growth factor receptor 3) promotes cell cycle via } \\
\text { activation of RAS/MAPK/AKT pathway }\end{array}$ & Lenvatinib, Pazopanib, Ponatinib, Regorafenib & & \\
\hline FLT3 & $\begin{array}{l}\text { FLT3 (FMS-like tyrosine kinase 3) activates signaling of Akt1, RAS, ERK, } \\
\text { and mTOR. }\end{array}$ & Midostaurin, Gilteritinib Quizartinib & & {$[9,24]$} \\
\hline FLT4 & $\begin{array}{l}\text { FLT4 (FMS like tyrosine kinase 4), also known as VEGFR-3 (vascular } \\
\text { endothelial growth factor receptor 3) }\end{array}$ & $\begin{array}{l}\text { Sorafenib, Sunitinib, Pazopanib, Axitinib, } \\
\text { Vandetanib, }\end{array}$ & & [25] \\
\hline GNAS & $\begin{array}{l}\text { GNAS (Guanine nucleotide binding protein, } \alpha \text { stimulating) regulates } \\
\text { adenylate cyclase via MAPK }\end{array}$ & Trametinib & & \\
\hline IDH1 & IDH1 (isocitrate dehydrogenases 1) & Azacitidine, Decitabine & & [26] \\
\hline $\mathrm{IDH} / 2$ & $\begin{array}{l}\text { IDH2 (isocitrate dehydrogenases 2) regulates citric acid (Krebs) cycle and } \\
\text { cell metabolism }\end{array}$ & Enasidenib & & [27] \\
\hline IGF1R & $\begin{array}{l}\text { IGF1R (insulin-like growth factor-1 receptor) mediates anti-apoptotic } \\
\text { signals }\end{array}$ & & Ganitumab NCT00562380 ** & \\
\hline JAK1 & JAK1 (Janus kinase 1) in involved in signal regulation & Tofacitinib & Fedratinib & [28] \\
\hline JAK2 & JAK2 (Janus kinase 2) is involved in signal regulation & Ruxolitinib & & [29] \\
\hline KIT & $\begin{array}{l}\text { KIT (also known as c-Kit or CD117), activates PI3K/Akt and } \\
\text { RAS/MAPK signaling pathway }\end{array}$ & Imatinib, Midastaurin & & \\
\hline KRAS & $\begin{array}{l}\text { KRAS (Kirsten rat sarcoma) regulates signal transduction via MAPK } \\
\text { pathway }\end{array}$ & $\begin{array}{l}\text { Cetuximab, Trametinib, Panitumumab, } \\
\text { Regorafenib }\end{array}$ & & [30] \\
\hline MAP2K1 & $\begin{array}{l}\text { MAP2K1 (mitogen-activated protein kinase } 1 \text { (MKK1 or MEK1) mediates } \\
\text { RAS/RAF/MAPK pathway }\end{array}$ & Cobimetinib, Selumetinib, Trametinib & & \\
\hline МАРЗК14 & $\begin{array}{l}\text { MAP3K14 (mitogen-activated protein kinase 14) also known as } \\
\text { NF-kappa-B-inducing kinase }\end{array}$ & Trametinib & & \\
\hline MLL & MLL (mixed lineage leukemia) encodes a histone methyltransferase & & EPZ-5676 NCT02141828** & \\
\hline MSH2 & $\begin{array}{l}\text { MSH2 (MutS homolog2) is a tumor suppressor encodes DNA mismatch } \\
\text { repair (MMR) protein } 2\end{array}$ & Atezolizumab, Nivolumab Pembrolizumab & & \\
\hline MSH6 & $\begin{array}{l}\text { MSH6 (MutS homolog 6) encodes DNA mismatch repair (MMR) protein } \\
6 \text { involved in DNA repair }\end{array}$ & Atezolizumab, Nivolumab Pembrolizumab & & \\
\hline MYC & MYC regulates cell cycle progression, apoptosis, proliferation & & BET inhibitors NCT02431260** & \\
\hline MYD88 & $\begin{array}{l}\text { MYD88 (myeloid differentiation primary response gene } 88 \text { ) activates } \\
\text { transcription factor NFkB }\end{array}$ & Ibrutinib, acalabrutinib (IRAK1 inh) & zanubrutinib & [7] \\
\hline $\mathrm{NF} 1 / 2$ & $\begin{array}{l}\text { NF1 (neurofibromin } 1 / 2 \text { ) a GTPase-activating negative regulator of the } \\
\text { RAS signaling pathway }\end{array}$ & Everolimus, Temsirolimus, Trametinib & & \\
\hline
\end{tabular}


Table 2. Cont.

\begin{tabular}{|c|c|c|c|c|}
\hline Gene Alteration & Gene Function & Examples of Potential on/off-Label Therapy & $\begin{array}{l}\text { Examples of Potential } \\
\text { Experimental } \\
\text { Therapy/Clinical Trial * }\end{array}$ & Ref. \\
\hline NRAS & $\begin{array}{l}\text { NRAS (neuroblastoma RAS) mediates signal transduction via } \\
\text { RAF/MEK/ERK and PI3K }\end{array}$ & Trametinib, Panitumumab & & [31] \\
\hline PALB2 & PALB2 (partner and localizer of BRCA2) & Olaparib & & [32] \\
\hline PDCD1LG2 & $\begin{array}{l}\text { Programmed cell death } 1 \text { ligand } 2 \text { (also known as CD273) essential for } \\
\text { T-cell proliferation }\end{array}$ & $\begin{array}{l}\text { Atezolizumab, Avelumab, Durvalumab, } \\
\text { Nivolumab, Pembrolizumab }\end{array}$ & & \\
\hline PIK3CA & $\begin{array}{l}\text { PIK3CA (phosphatidylinositol 3-kinase (PI3K), which regulates the } \\
\text { PI3K/AKT/MTOR axis }\end{array}$ & $\begin{array}{l}\text { Everolimus, Temsirolimus, Copanlisib, Duvalisib, } \\
\text { Idelalisib }\end{array}$ & Taselisib NCT02465060 ** & \\
\hline PIK3R1 & PIK3R1 (PI3K regulatory subunit alpha) & Copanlisib & NCT02369016** & \\
\hline PTCH1 & $\begin{array}{l}\text { PTCH1 (Protein patched homolog 1) is a receptor for Sonic hedgehog } \\
\text { (Shh) for gene transcription }\end{array}$ & Vismodegib, Sonidegib & & [33] \\
\hline PTEN & $\begin{array}{l}\text { PTEN (phosphatase and tensin homolog) is a tumor suppressor, } \\
\text { functions via PI3K/AKT/mTOR pathway }\end{array}$ & Everolimus, Temsirolimus & & [34] \\
\hline PTPN11 & $\begin{array}{l}\text { PTPN11 (Tyrosine-protein phosphatase non-receptor type 11) activates } \\
\text { PI3K, MEK axis }\end{array}$ & Trametinib, & & [35] \\
\hline RET & RET (rearranged during transfection) is a proto-oncogene & Cabozantinib, Sorafenib, Vandetanib, Lenvatinib & & [36] \\
\hline RUNX1 & $\begin{array}{l}\text { RUNX1 (Runt-related transcription factor, also known as acute myeloid } \\
\text { leukemia } 1 \text { protein (AML1), core-binding factor subunit alpha } 2 \text { (CBFA2) } \\
\text { is a tumor suppressor }\end{array}$ & & $\begin{array}{l}\text { Mocetinostat (MGCD0103) or } \\
\text { Sorafenib NCT00217646 ** }\end{array}$ & \\
\hline STAT3 & $\begin{array}{l}\text { STAT3 (signal transducer and activator of transcription 3) encodes a } \\
\text { transcription factor }\end{array}$ & & AZD9150 (NCT01839604) ** & \\
\hline STK11 & STK11 (serine/threonine kinase 11) functions as a tumor suppressor gene & Dasatinib, Bosutinib, Everolimus, Temsirolimus & & \\
\hline TET2 & TET2 (Tet methylcytosine dioxygenase 2) regulates DNA demethylation & Azacitidine, Decitabine & & [37] \\
\hline TP53 & $\begin{array}{l}\text { TP53 (Tumor protein p53) is a tumor suppressor; loss leads to } \\
\text { overexpression of VEGF levels }\end{array}$ & Bevacizumab, Pazopanib & $\begin{array}{l}\text { Wee-1 inh, MDM inh, } \\
\text { PRIMA-1MET inhibitors. }\end{array}$ & [38] \\
\hline VHL & $\begin{array}{l}\text { VHL (von Hippel-Lindau) is a tumor suppressor activates the } \\
\text { HIF/VEGF pathway }\end{array}$ & $\begin{array}{l}\text { Axitinib, Bevacizumab, Everolimus, Pazopanib, } \\
\text { Sorafenib, Sunitinib, Temsirolimus, Vandetanib, }\end{array}$ & & \\
\hline XPO1 & XPO1 (exportin-1) regulates nuclear export of tumor suppressor genes & & Selinexor NCT02227251 & \\
\hline
\end{tabular}

${ }^{*}$ Experimental drugs in clinical trials are generally only mentioned if there are no FDA-approved drugs that impact that target. ${ }^{* *}$ Numbers refer to clinicaltrials.gov identifier (https://clinicaltrials.gov/ct2/show). 


\section{Discussion}

Our study demonstrates that the majority of hematologic tumors $(\sim 97 \%)$ had adequate tissue for CGP interrogation. Further, of the 227 patients with adequate tissue, 75\% harbored alterations that could be prosecuted by a drug already in the clinical setting (Figure 1) (by an FDA-approved, on-label drug (14\%) or by an FDA-approved off-label drug (an additional $49 \%$ of patients) with the rest targetable by experimental drugs in clinical trials). This finding is similar to observations in solid tumors where up to $70 \%$ of patients have an alteration that was theoretically pharmacologically tractable with an approved drug, and over $90 \%$ of patients have a potentially druggable alteration if experimental drugs are included [39]. In contrast to solid tumors, however, with few exceptions, the clinical utility of CGP for therapeutic decision-making for hematological malignancies has been limited and genomic information has largely been confined to diagnosis, classification, and prognostication. An example of such use is TP53 or ATM mutations in chronic lymphocytic leukemia (CLL), which predict resistance to or short duration of response to chemotherapeutic agents [40]. Still, therapeutic matching in AML is beginning to be reported, with notable examples being the FLT3 inhibitor midostaurin and gilteritinib or the isocitrate dehydrogenase (IDH) inhibitors for patients with cognate aberrations [9,27]. Overall, however, master precision medicine studies matching patients to diverse cognate agents based on CGP are now being widely performed across solid tumors $[2,3]$ but are in nascent stages in the hematologic field.

Interestingly, as in solid tumors, there was great diversity in genomic portfolios in our patients [1]. Indeed, 148 distinct genes were altered in at least one patient and there were 546 unique genomic alterations (Table 1). The vast majority of patients ( $95.5 \%$ of the 227 patients with adequate tissue) had distinct genomic signatures. These findings suggest that customized combinations of drugs may be needed for optimal matching.

The successful application of molecularly informed therapy has been demonstrated in Waldenström's macroglobulinemia (WM) lymphoplasmacytic lymphoma (LPL) where about 90\% of patients have a dominant mutation in $M Y D 88^{\mathrm{L} 265 \mathrm{P}}$, an adapter protein used by toll-like receptors that mediate signaling through Bruton tyrosine kinase (BTK) to promote proliferation and survival [41]. In a phase 2 trial, inhibition of BTK with ibrutinib achieved an overall response rate of $91 \%$ in previously treated patients with WM [7]. Furthermore, as expected, the response rate to ibrutinib was significantly higher in patients with MYD 88 mutations vs. wild-type MYD 88 genotype [7]. In our cohort, the MYD88 L265P mutation was found in one patient with WM as well as in four (of 18) patients with diffuse large B-cell lymphoma (DLBCL), including one patient with a primary central nervous system lymphoma (PCSNL). In the literature, MYD88 mutations have also been identified in marginal zone lymphoma (MZL), CLL, DLBCL and PCNSL [42-45]. Preliminary data from a phase I trial of single-agent ibrutnib in four patients with PCNSL demonstrated responses in two of the three patients evaluated [46]. Our data further confirms that mutations in MYD 88 are readily identified by NGS. Trials in patients with diverse malignancies and MYD88 mutations with BTK inhibitors may be warranted.

Activating mutations in BRAF were found in CLL ( $N=3$ of 39 patients; two with BRAF G469A and one with $B R A F$ V600E), multiple myeloma ( $N=1$ of 17; BRAF V600E), hairy cell leukemia (HCL) $(N=1$ of 1 ; BRAF V600E) and Erdheim Chester disease (ECD) $(N=1$ of 1 patient; BRAF V600E). These mutations are potentially targetable by the BRAF inhibitors vemurafenib and dabrafenib and the MEK inhibitors trametinib and cobimetinib $[4,17]$. BRAF alterations have been identified as a dominant driver mutation and as a biomarker for sensitivity to BRAF inhibition in HCL, ECD, and myeloma [8,47-49]. BRAF alterations have been noted previously in $3 \%$ of patients with CLL [50]. In our studies, two CLL patients $(5 \%)$ had mutations leading to alanine to glycine substitution at position 469 , which is an activating mutation in other tumors and confers sensitivity to BRAF inhibition [51]. To our knowledge, this mutation has not been targeted in CLL previously. More recently, Wander et al. also reported a t-AML patient with a BRAF V600E mutation, who was refractory to several induction regimens, yet demonstrated a remarkable response to combined targeted BRAF/MEK therapy (with dabrafenib and trametinib) as evidenced by restoration of normal 
hematopoiesis, clearance of peripheral blasts, and a significant reduction in marrow leukemic burden with a concordant decrease in the BRAF V600E allelic burden [52]. Although transient, this patient's response serves as a proof of concept that targeting oncogenic driver mutations may have similar efficacy in hematologic malignancies as in solid tumors supporting the emerging paradigm of designing targeted therapies based on the presence of actionable lesions [53].

TMB has been shown to correlate to response with checkpoint inhibitors in solid tumors [54]. The vast majority of our 219 patients in whom TMB could be evaluated had a low TMB, but $12 \%(N=26)$ had an intermediate burden and $2 \%(N=5$ patients) had high TMB. Further, the mutational burden was significantly higher in lymphoid versus myeloid malignancies ( 2.5 versus 0.9 mutations/MB, respectively $(p=0.0012)$. This data is consistent with our previous analysis that showed that $32 \%$ of patients with lymphoid malignancies had intermediate to high TMB [55]. Three of our patients with higher TMB had mismatch repair gene alterations; in the solid tumor field, the PD-1 inhibitor pembrolizumab has recently received approval for all patients with solid tumors and microsatellite instability-high disease (which is due to mismatch repair alterations and is associated with a high TMB and high response rate to anti-PD1 agents [56]. These results suggest that there may be a subset of patients with hematologic malignancies who are amenable to response to checkpoint inhibitors as well.

Despite a wealth of clinical experience with molecularly matched therapies in solid tumor oncology, some of these targetable alterations remain unexplored within the clinical realm of hematology and present one of the major limitations of our study. This is partly due to the fact that many of the theoretically applicable molecules are FDA-approved primarily in solid tumors [57]. Furthermore, there is still an incomplete consensus regarding what represents a targetable alteration, and the necessary level of evidence needed to support the use of cognate agents in the clinic remains a matter of debate. Thus, further studies assessing the role of therapy matched to genomic portfolios across hematologic malignancies are certainly warranted.

\section{Patients and Methods}

\subsection{Patients}

We analyzed the genomic alterations by CGP and clinical characteristics of 235 patients with diverse hematologic cancers seen at the UCSD Moores Cancer Center (La Jolla, CA, USA) from October 2012 through December 2016. This study was performed and consents obtained in accordance with the guidelines of the UCSD Institutional Review Board (NCT02478931) (Center for Personalized Cancer Therapy) (Center for Personalized Cancer Therapy).

\subsection{Comprehensive Genomic Profiling (CGP)}

We conducted CGP on tumor samples from lymph nodes, peripheral blood, bone marrow, or tissue using FoundationOne Heme ${ }^{\circledR}$ (F1H; Foundation Medicine Inc., Cambridge, MA, USA), a clinical grade, high-throughput, hybridization capture-based NGS assay for targeted sequencing of all exons of 406 genes as well as RNA sequencing of 265 genes. F1H is a validated clinical laboratory improvement amendments (CLIA)-approved, NY-state approved assay, and the methods used have been previously reported in detail [58,59]. It is capable of simultaneously identifying all genomic alterations, including insertions/deletions, base pair substitutions, copy number alterations (CNA), and select gene rearrangements. Variants of unknown significance (VUSs) were not included in any of our analyses except for tumor mutational burden (TMB) assessment.

\subsection{Tumor Mutational Burden (TMB)}

For TMB, the number of somatic mutations detected on NGS (interrogating 1.2 megabase $(\mathrm{Mb})$ of the genome) are quantified and that value extrapolated to the whole exome using a validated algorithm $[60,61]$. Alterations likely or known to be bona fide oncogenic drivers and germline polymorphisms are excluded. TMB was measured in mutations per MB. TMB levels were divided 
into three groups (per Foundation Medicine template): Low (1-5 mutations/MB), intermediate (6-19 mutations/MB), and high ( $\geq 20$ mutations/MB).

\subsection{Definition of a Potentially Actionable Alteration}

An alteration was designated as potentially actionable if there is $\geq 1$ FDA-approved drug(s) or experimental compounds in a clinical protocol that may impact the function of the protein product of the alteration or its immediate downstream effectors, or that differentially distinguishes the protein in cancerous versus normal cells. Small molecule inhibitors with $50 \%$ low inhibitory concentration for the target and antibodies that recognize the protein were considered as impacting the target.

\subsection{Data Analysis and Statistics}

Pertinent data including patient demographics, tumor histology, and tissue source as well as molecular testing results, number, and type of genomic alterations, were extracted from patients' electronic medical records. Descriptive statistics (medians, means, ranges, and frequencies) were used.

\section{Conclusions}

In conclusion, we found that most patients with hematologic malignancies exhibit complex molecular profiles that capture an array of oncogenic pathways across various histologies. The vast majority of individuals have at least one or more genomic alterations that are potentially actionable with existing drugs. A small subset of patients have intermediate/high tumor mutational burden, a variable that has previously correlated with response to checkpoint inhibitor immunotherapy. These observations present a window of opportunity for clinical trials to rationally test the application of genomically targeted therapeutics or immunotherapy, particularly in relapsed/refractory patients who have either exhausted or are unable to tolerate standard chemotherapy.

Author Contributions: N.G. wrote the manuscript; N.G., R.B., M.C., A.G., M.W., C.M., C.J., R.K. performed research; L.K., P.T., H.Y. analyzed data, J.-A.V., T.I.M. and, V.M. assisted with genomic profiling through Foundation Medicine. All authors edited the manuscript.

Funding: This research was funded by National Cancer Institute, grant number: P30 CA023100.

Acknowledgments: Moores Cancer Center faculty/staff and their patients. Funded in part by the Joan and Irwin Jacobs Fund philanthropic fund and the National Cancer Institute grant P30 CA023100.

Conflicts of Interest: Miller, Mughal and Vergilio are employees and equity holders of Foundation Medicine. Kurzrock receives research funding from Incyte, Genentech, Merck, Serono, Pfizer, Sequenom, Foundation Medicine, and Guardant, as well as consultant fees from X-Biotech, Roche, and Actuate Therapeutics and has an ownership interest in Curematch Inc. Bejar has received consultant fees from Genoptix, AbbVie, Celgene, Otsuka, and Foundation Medicine. Jamieson is a co-founder of Wintherix Inc. and Impact Biomedicines Inc. and receives unrestricted research funding from Celgene, J \& J and GSK. Galanina, Goodman, and Wieduwilt have no disclosures to declare.

\section{References}

1. Wheler, J.; Lee, J.J.; Kurzrock, R. Unique molecular landscapes in cancer: Implications for individualized, curated drug combinations. Cancer Res. 2014, 74, 7181-7184. [CrossRef] [PubMed]

2. Schwaederle, M.; Parker, B.A.; Schwab, R.B.; Daniels, G.A.; Piccioni, D.E.; Kesari, S.; Helsten, T.L.; Bazhenova, L.A.; Romero, J.; Fanta, P.T.; et al. Precision Oncology: The UC San Diego Moores Cancer Center PREDICT Experience. Mol. Cancer Ther. 2016, 15, 743-752. [CrossRef] [PubMed]

3. Wheler, J.J.; Janku, F.; Naing, A.; Li, Y.; Stephen, B.; Zinner, R.; Subbiah, V.; Fu, S.; Karp, D.; Falchook, G.S.; et al. Cancer Therapy Directed by Comprehensive Genomic Profiling: A Single Center Study. Cancer Res. 2016, 76, 3690-3701. [CrossRef] [PubMed]

4. Chapman, P.B.; Hauschild, A.; Robert, C.; Haanen, J.B.; Ascierto, P.; Larkin, J.; Dummer, R.; Garbe, C.; Testori, A.; Maio, M.; et al. Improved survival with vemurafenib in melanoma with BRAF V600E mutation. N. Engl. J. Med. 2011, 364, 2507-2516. [CrossRef] [PubMed] 
5. Rosell, R.; Carcereny, E.; Gervais, R.; Vergnenegre, A.; Massuti, B.; Felip, E.; Palmero, R.; Garcia-Gomez, R.; Pallares, C.; Sanchez, J.M.; et al. Erlotinib versus standard chemotherapy as first-line treatment for European patients with advanced EGFR mutation-positive non-small-cell lung cancer (EURTAC): A multicentre, open-label, randomised phase 3 trial. Lancet Oncol. 2012, 13, 239-246. [CrossRef]

6. Zelenetz, A.D.; Gordon, L.I.; Wierda, W.G.; Abramson, J.S.; Advani, R.H.; Andreadis, C.B.; Bartlett, N.; Byrd, J.C.; Fayad, L.E.; Fisher, R.I.; et al. Diffuse Large B-Cell Lymphoma Version 1.2016. J. Natl. Compr. Cancer Netw. JNCCN 2016, 14, 196-231. [CrossRef]

7. Treon, S.P.; Xu, L.; Hunter, Z. MYD88 Mutations and Response to Ibrutinib in Waldenstrom's Macroglobulinemia. N. Engl. J. Med. 2015, 373, 584-586. [CrossRef] [PubMed]

8. Munoz, J.; Schlette, E.; Kurzrock, R. Rapid response to vemurafenib in a heavily pretreated patient with hairy cell leukemia and a BRAF mutation. J. Clin. Oncol. 2013, 31, e351-e352. [CrossRef]

9. Stone, R.M.; Mandrekar, S.J.; Sanford, B.L.; Laumann, K.; Geyer, S.; Bloomfield, C.D.; Thiede, C.; Prior, T.W.; Dohner, K.; Marcucci, G.; et al. Midostaurin plus Chemotherapy for Acute Myeloid Leukemia with a FLT3 Mutation. N. Engl. J. Med. 2017, 377, 454-464. [CrossRef]

10. Subramanian, A.; Tamayo, P.; Mootha, V.K.; Mukherjee, S.; Ebert, B.L.; Gillette, M.A.; Paulovich, A.; Pomeroy, S.L.; Golub, T.R.; Lander, E.S.; et al. Gene set enrichment analysis: a knowledge-based approach for interpreting genome-wide expression profiles. Proc. Natl. Acad. Sci. USA 2005, 102, 15545-15550. [CrossRef]

11. Liberzon, A.; Subramanian, A.; Pinchback, R.; Thorvaldsdottir, H.; Tamayo, P.; Mesirov, J.P. Molecular signatures database (MSigDB) 3.0. Bioinformatics 2011, 27, 1739-1740. [CrossRef] [PubMed]

12. Liberzon, A.; Birger, C.; Thorvaldsdottir, H.; Ghandi, M.; Mesirov, J.P.; Tamayo, P. The Molecular Signatures Database (MSigDB) hallmark gene set collection. Cell Syst. 2015, 1, 417-425. [CrossRef] [PubMed]

13. Samadder, N.J.; Neklason, D.W.; Boucher, K.M.; Byrne, K.R.; Kanth, P.; Samowitz, W.; Jones, D.; Tavtigian, S.V.; Done, M.W.; Berry, T.; et al. Effect of Sulindac and Erlotinib vs Placebo on Duodenal Neoplasia in Familial Adenomatous Polyposis: A Randomized Clinical Trial. JAMA 2016, 315, 1266-1275. [CrossRef] [PubMed]

14. Katoh, M. Functional and cancer genomics of ASXL family members. Br. J. Cancer 2013, 109, $299-306$. [CrossRef] [PubMed]

15. Cremona, C.A.; Behrens, A. ATM signalling and cancer. Oncogene 2014, 33, 3351-3360. [CrossRef] [PubMed]

16. Roberts, A.W.; Davids, M.S.; Pagel, J.M.; Kahl, B.S.; Puvvada, S.D.; Gerecitano, J.F.; Kipps, T.J.; Anderson, M.A.; Brown, J.R.; Gressick, L.; et al. Targeting BCL2 with Venetoclax in Relapsed Chronic Lymphocytic Leukemia. N. Engl. J. Med. 2015, 374, 311-322. [CrossRef] [PubMed]

17. Robert, C.; Karaszewska, B.; Schachter, J.; Rutkowski, P.; Mackiewicz, A.; Stroiakovski, D.; Lichinitser, M.; Dummer, R.; Grange, F.; Mortier, L.; et al. Improved overall survival in melanoma with combined dabrafenib and trametinib. N. Engl. J. Med. 2015, 372, 30-39. [CrossRef]

18. Wiestner, A. Targeting B-Cell receptor signaling for anticancer therapy: the Bruton's tyrosine kinase inhibitor ibrutinib induces impressive responses in B-cell malignancies. J. Clin. Oncol. 2013, 31, 128-130. [CrossRef]

19. Sherr, C.J.; Beach, D.; Shapiro, G.I. Targeting CDK4 and CDK6: From Discovery to Therapy. Cancer Discov. 2016, 6, 353-367. [CrossRef]

20. Davis, R.E.; Ngo, V.N.; Lenz, G.; Tolar, P.; Young, R.; Romesser, P.B.; Kohlhammer, H.; Lamy, L.; Zhao, H.; Yang, Y.; et al. Chronic Active B Cell Receptor Signaling in Diffuse Large B Cell Lymphoma. Nature 2010, 463, 88-92. [CrossRef]

21. Scala, S. Molecular Pathways: Targeting the CXCR4-CXCL12 Axis-Untapped Potential in the Tumor Microenvironment. Clin. Cancer Res. 2015, 21, 4278-4285. [CrossRef] [PubMed]

22. Metzeler, K.H.; Walker, A.; Geyer, S.; Garzon, R.; Klisovic, R.B.; Bloomfield, C.D.; Blum, W.; Marcucci, G. DNMT3A Mutations and Response to the Hypomethylating Agent Decitabine in Acute Myeloid Leukemia. Leukemia 2012, 26, 1106-1107. [CrossRef] [PubMed]

23. McCabe, M.T.; Ott, H.M.; Ganji, G.; Korenchuk, S.; Thompson, C.; Van Aller, G.S.; Liu, Y.; Graves, A.P.; Della Pietra, A., 3rd; Diaz, E.; et al. EZH2 inhibition as a therapeutic strategy for lymphoma with EZH2-activating mutations. Nature 2012, 492, 108-112. [CrossRef] [PubMed]

24. Mizuki, M.; Fenski, R.; Halfter, H.; Matsumura, I.; Schmidt, R.; Muller, C.; Gruning, W.; Kratz-Albers, K.; Serve, S.; Steur, C.; et al. FLT3 mutations from patients with acute myeloid leukemia induce transformation of 32D cells mediated by the Ras and STAT5 pathways. Blood 2000, 96, 3907-3914. [PubMed] 
25. Dias, S.; Choy, M.; Alitalo, K.; Rafii, S. Vascular endothelial growth factor (VEGF)-C signaling through FLT-4 (VEGFR-3) mediates leukemic cell proliferation, survival, and resistance to chemotherapy. Blood 2002, 99, 2179-2184. [CrossRef] [PubMed]

26. Emadi, A.; Faramand, R.; Carter-Cooper, B.; Tolu, S.; Ford, L.A.; Lapidus, R.G.; Wetzler, M.; Wang, E.S.; Etemadi, A.; Griffiths, E.A. Presence of isocitrate dehydrogenase mutations may predict clinical response to hypomethylating agents in patients with acute myeloid leukemia. Am. J. Hematol. 2015, 90, E77-E79. [CrossRef] [PubMed]

27. Stein, E.M.; DiNardo, C.D.; Pollyea, D.A.; Fathi, A.T.; Roboz, G.J.; Altman, J.K.; Stone, R.M.; DeAngelo, D.J.; Levine, R.L.; Flinn, I.W.; et al. Enasidenib in mutant IDH2 relapsed or refractory acute myeloid leukemia. Blood 2017, 130, 722-731. [CrossRef]

28. Boyle, D.L.; Soma, K.; Hodge, J.; Kavanaugh, A.; Mandel, D.; Mease, P.; Shurmur, R.; Singhal, A.K.; Wei, N.; Rosengren, S.; et al. The JAK inhibitor tofacitinib suppresses synovial JAK1-STAT signalling in rheumatoid arthritis. Ann. Rheum. Dis. 2015, 74, 1311-1316. [CrossRef]

29. Jamieson, C.H.; Gotlib, J.; Durocher, J.A.; Chao, M.P.; Mariappan, M.R.; Lay, M.; Jones, C.; Zehnder, J.L.; Lilleberg, S.L.; Weissman, I.L. The JAK2 V617F mutation occurs in hematopoietic stem cells in polycythemia vera and predisposes toward erythroid differentiation. Proc. Natl. Acad. Sci. USA 2006, 103, 6224-6229. [CrossRef]

30. Infante, J.R.; Fecher, L.A.; Falchook, G.S.; Nallapareddy, S.; Gordon, M.S.; Becerra, C.; DeMarini, D.J.; Cox, D.S.; Xu, Y.; Morris, S.R.; et al. Safety, pharmacokinetic, pharmacodynamic, and efficacy data for the oral MEK inhibitor trametinib: A phase 1 dose-escalation trial. Lancet. Oncol. 2012, 13, 773-781. [CrossRef]

31. Pylayeva-Gupta, Y.; Grabocka, E.; Bar-Sagi, D. RAS oncogenes: Weaving a tumorigenic web. Nat. Rev. Cancer 2011, 11, 761-774. [CrossRef] [PubMed]

32. Sy, S.M.; Huen, M.S.; Chen, J. PALB2 is an integral component of the BRCA complex required for homologous recombination repair. Proc. Natl. Acad. Sci. USA 2009, 106, 7155-7160. [CrossRef] [PubMed]

33. Sekulic, A.; Migden, M.R.; Oro, A.E.; Dirix, L.; Lewis, K.D.; Hainsworth, J.D.; Solomon, J.A.; Yoo, S.; Arron, S.T.; Friedlander, P.A.; et al. Efficacy and safety of vismodegib in advanced basal-cell carcinoma. N. Engl. J. Med. 2012, 366, 2171-2179. [CrossRef] [PubMed]

34. Spinelli, L.; Lindsay, Y.E.; Leslie, N.R. PTEN inhibitors: An evaluation of current compounds. Adv. Biol. Regul. 2015, 57, 102-111. [CrossRef] [PubMed]

35. Grossmann, K.S.; Rosario, M.; Birchmeier, C.; Birchmeier, W. The tyrosine phosphatase Shp2 in development and cancer. Adv. Cancer Res. 2010, 106, 53-89. [CrossRef] [PubMed]

36. Sabari, J.K.; Siau, E.D.; Drilon, A. Targeting RET-rearranged lung cancers with multikinase inhibitors. Oncoscience 2017, 4, 23-24. [CrossRef] [PubMed]

37. Bejar, R.; Lord, A.; Stevenson, K.; Bar-Natan, M.; Perez-Ladaga, A.; Zaneveld, J.; Wang, H.; Caughey, B.; Stojanov, P.; Getz, G.; et al. TET2 mutations predict response to hypomethylating agents in myelodysplastic syndrome patients. Blood 2014, 124, 2705-2712. [CrossRef] [PubMed]

38. Schwaederle, M.; Lazar, V.; Validire, P.; Hansson, J.; Lacroix, L.; Soria, J.C.; Pawitan, Y.; Kurzrock, R. VEGF-A Expression Correlates with TP53 Mutations in Non-Small Cell Lung Cancer: Implications for Antiangiogenesis Therapy. Cancer Res. 2015, 75, 1187-1190. [CrossRef]

39. Schwaederle, M.; Daniels, G.A.; Piccioni, D.E.; Fanta, P.T.; Schwab, R.B.; Shimabukuro, K.A.; Parker, B.A.; Kurzrock, R. On the Road to Precision Cancer Medicine: Analysis of Genomic Biomarker Actionability in 439 Patients. Mol. Cancer Ther. 2015, 14, 1488-1494. [CrossRef]

40. Choi, M.; Kipps, T.; Kurzrock, R. ATM Mutations in Cancer: Therapeutic Implications. Mol. Cancer Ther. 2016, 15, 1781-1791. [CrossRef]

41. Treon, S.P.; Xu, L.; Yang, G.; Zhou, Y.; Liu, X.; Cao, Y.; Sheehy, P.; Manning, R.J.; Patterson, C.J.; Tripsas, C.; et al. MYD88 L265P somatic mutation in Waldenstrom's macroglobulinemia. N. Engl. J. Med. 2012, 367, 826-833. [CrossRef] [PubMed]

42. Martinez-Lopez, A.; Curiel-Olmo, S.; Mollejo, M.; Cereceda, L.; Martinez, N.; Montes-Moreno, S.; Almaraz, C.; Revert, J.B.; Piris, M.A. MYD88 (L265P) somatic mutation in marginal zone B-cell lymphoma. Am. J. Surg. Pathol. 2015, 39, 644-651. [CrossRef] [PubMed]

43. Baliakas, P.; Hadzidimitriou, A.; Agathangelidis, A.; Rossi, D.; Sutton, L.A.; Kminkova, J.; Scarfo, L.; Pospisilova, S.; Gaidano, G.; Stamatopoulos, K.; et al. Prognostic relevance of MYD88 mutations in CLL: The jury is still out. Blood 2015, 126, 1043-1044. [CrossRef] [PubMed] 
44. Choi, J.W.; Kim, Y.; Lee, J.H.; Kim, Y.S. MYD88 expression and L265P mutation in diffuse large B-cell lymphoma. Hum. Pathol. 2013, 44, 1375-1381. [CrossRef] [PubMed]

45. Gonzalez-Aguilar, A.; Idbaih, A.; Boisselier, B.; Habbita, N.; Rossetto, M.; Laurenge, A.; Bruno, A.; Jouvet, A.; Polivka, M.; Adam, C.; et al. Recurrent mutations of MYD88 and TBL1XR1 in primary central nervous system lymphomas. Clin. Cancer Res. Off. J. Am. Assoc. Cancer Res. 2012, 18, 5203-5211. [CrossRef] [PubMed]

46. Grommes, C.; Kaley, T.J.; Nolan, C.; Omuro, A.M.P.; Wolfe, J.; Mellinghoff, I.K.; DeAngelis, L.M. Phase I study of single agent ibrutinib in recurrent/refractory primary (PCNSL) and secondary CNS lymphoma (SCNSL). J. Clin. Oncol. 2016, 34, 2046. [CrossRef]

47. Tiacci, E.; Park, J.H.; De Carolis, L.; Chung, S.S.; Broccoli, A.; Scott, S.; Zaja, F.; Devlin, S.; Pulsoni, A.; Chung, Y.R.; et al. Targeting Mutant BRAF in Relapsed or Refractory Hairy-Cell Leukemia. N. Engl. J. Med. 2015, 373, 1733-1747. [CrossRef]

48. Tiacci, E.; Trifonov, V.; Schiavoni, G.; Holmes, A.; Kern, W.; Martelli, M.P.; Pucciarini, A.; Bigerna, B.; Pacini, R.; Wells, V.A.; et al. BRAF mutations in hairy-cell leukemia. N. Engl. J. Med. 2011, 364, 2305-2315. [CrossRef]

49. Andrulis, M.; Lehners, N.; Capper, D.; Penzel, R.; Heining, C.; Huellein, J.; Zenz, T.; von Deimling, A.; Schirmacher, P.; Ho, A.D.; et al. Targeting the BRAF V600E mutation in multiple myeloma. Cancer Discov. 2013, 3, 862-869. [CrossRef]

50. Jebaraj, B.M.; Kienle, D.; Buhler, A.; Winkler, D.; Dohner, H.; Stilgenbauer, S.; Zenz, T. BRAF mutations in chronic lymphocytic leukemia. Leukemia Lymphoma 2013, 54, 1177-1182. [CrossRef]

51. Flaherty, K.T.; McArthur, G. BRAF, a target in melanoma: Implications for solid tumor drug development. Cancer 2010, 116, 4902-4913. [CrossRef] [PubMed]

52. Wander, S.A.; Hasserjian, R.P.; Oduro, K.; Glomski, K.; Nardi, V.; Cote, G.M.; Graubert, T.A.; Brunner, A.M.; Chen, Y.B.A.; Fathi, A.T. Combined Targeted Therapy for BRAF-Mutant, Treatment-Related Acute Myeloid Leukemia. JCO Precis. Oncol. 2017, 1, 1-7. [CrossRef]

53. Turski, M.L.; Vidwans, S.J.; Janku, F.; Garrido-Laguna, I.; Munoz, J.; Schwab, R.; Subbiah, V.; Rodon, J.; Kurzrock, R. Genomically Driven Tumors and Actionability across Histologies: BRAF-Mutant Cancers as a Paradigm. Mol. Cancer Ther. 2016, 15, 533-547. [CrossRef] [PubMed]

54. Rizvi, N.A.; Hellmann, M.D.; Snyder, A.; Kvistborg, P.; Makarov, V.; Havel, J.J.; Lee, W.; Yuan, J.; Wong, P.; Ho, T.S.; et al. Cancer immunology. Mutational landscape determines sensitivity to PD-1 blockade in non-small cell lung cancer. Science 2015, 348, 124-128. [CrossRef] [PubMed]

55. Goodman, A.M.; Choi, M.; Wieduwilt, M.; Mulroney, C.; Costello, C.; Frampton, G.; Miller, V.; Kurzrock, R. Next Generation Sequencing Reveals Potentially Actionable Alterations in the Majority of Patients with Lymphoid Malignancies. JCO Precis. Oncol. 2017, 1. [CrossRef]

56. Fashoyin-Aje, L.; Donoghue, M.; Chen, H.; He, K.; Veeraraghavan, J.; Goldberg, K.B.; Keegan, P.; McKee, A.E.; Pazdur, R. FDA Approval Summary: Pembrolizumab for Recurrent Locally Advanced or Metastatic Gastric or Gastroesophageal Junction Adenocarcinoma Expressing PD-L1. Oncologist 2018. [CrossRef]

57. Schwaederle, M.; Parker, B.A.; Schwab, R.B.; Fanta, P.T.; Boles, S.G.; Daniels, G.A.; Bazhenova, L.A.; Subramanian, R.; Coutinho, A.C.; Ojeda-Fournier, H.; et al. Molecular tumor board: The University of California-San Diego Moores Cancer Center experience. Oncologist 2014, 19, 631-636. [CrossRef]

58. He, J.; Abdel-Wahab, O.; Nahas, M.K.; Wang, K.; Rampal, R.K.; Intlekofer, A.M.; Patel, J.; Krivstov, A.; Frampton, G.M.; Young, L.E.; et al. Integrated genomic DNA/RNA profiling of hematologic malignancies in the clinical setting. Blood 2016, 127, 3004-3014. [CrossRef]

59. Frampton, G.M.; Fichtenholtz, A.; Otto, G.A.; Wang, K.; Downing, S.R.; He, J.; Schnall-Levin, M.; White, J.; Sanford, E.M.; An, P.; et al. Development and validation of a clinical cancer genomic profiling test based on massively parallel DNA sequencing. Nat. Biotechnol. 2013, 31, 1023-1031. [CrossRef] 
60. Chalmers, Z.R.; Connelly, C.F.; Fabrizio, D.; Gay, L.; Ali, S.M.; Ennis, R.; Schrock, A.; Campbell, B.; Shlien, A.; Chmielecki, J.; et al. Analysis of 100,000 human cancer genomes reveals the landscape of tumor mutational burden. Genome Med. 2017, 9. [CrossRef]

61. Kowanetz, M.; Zou, W.; Shames, D.S.; Cummings, C.; Rizvi, N.; Spira, A.I.; Frampton, G.M.; Leveque, V.; Flynn, S.; Mocci, S.; et al. Tumor mutation load assessed by FoundationOne (FM1) is associated with improved efficacy of atezolizumab (atezo) in patients with advanced NSCLC. Ann. Oncol. 2016, 27. [CrossRef]

(C) 2018 by the authors. Licensee MDPI, Basel, Switzerland. This article is an open access article distributed under the terms and conditions of the Creative Commons Attribution (CC BY) license (http:/ / creativecommons.org/licenses/by/4.0/). 